\title{
Creating a supportive environment is very important to reduce STI, HIV/AIDS and infectious disease
}

SM Rezaul Islam

From $16^{\text {th }}$ International Symposium on HIV and Emerging Infectious Diseases

Marseille, France. 24-26 March 2010

\section{Background}

The aim is to create a supportive environment for HIV, AIDS and STI prevention program among hotel based sex worker in Chittagong, Bangladesh through social mobilization.

\section{Methods}

With a view to achieve the aim we form a Project Facilitation Team (PFT). The member was selected as representatives from hotel owners, Chittagong City Corporation, the Department of Police, Department of Health, Social Workers, Media Professionals, Law enforcement agencies, Department of Women Affairs, Muslim religious leader and members from other NGO working in the city.

\section{Results}

The Project Facilitation Team (PFT) member has been seating quarterly basis to review program progress. The PFT members advise and cooperate for reducing barriers and mobilizing social support for project activities take place. Especially they have been Facilitating regular contact with key stakeholders, including sex workers, member of law enforcement agencies, hotel owners and workers. As a result police is not harassing our Peer Educator and they are allowing to conduct the Behavior Change Communication (BCC) session at hotel and the hotel owner and hotel management are giving the free access to work with the sex worker in their hotel i.e. conduction of BCC session, distribution of condom and lubricant.

Correspondence: smrezaulislam@yahoo.com

SHED Foundation, Chittagong, Bangladesh

B̈oMed Central o 2010 Islam; licensee BioMed Central Ltd.

\section{Discussion}

Formation and functioning of Project Facilitation Team is very effective to create a supportive environment for reducing the STI, HIV/AIDS and other infectious dissease because the members of the team can support the project's implementation with their local knowledge and influence. So, it can be a best model for other country.

Published: 11 May 2010

doi:10.1186/1742-4690-7-S1-P139

Cite this article as: Islam: Creating a supportive environment is very important to reduce STI, HIV/AIDS and infectious disease. Retrovirology 2010 7(Suppl 1):P139.
Submit your next manuscript to BioMed Central and take full advantage of:

- Convenient online submission

- Thorough peer review

- No space constraints or color figure charges

- Immediate publication on acceptance

- Inclusion in PubIMed, CAS, Scopus and Google Scholar

- Research which is freely available for redistribution

Submit your manuscript at www.biomedcentral.com/submit 